\title{
The Risk and Protective Factor in the Resilience Development of Indonesian Navy Soldier's Wives
}

\author{
Wiwik Triwidiyanti ${ }^{1, *}$, Yusti Probowati $R^{2}$, Andrian Pramadi ${ }^{3}$ \\ 1, 2, 3 Faculty of Psychology Doctoral Program, University of Surabaya (UBAYA), Surabaya, Indonesia \\ *Corresponding Author: wiwikseger51@gmail.com
}

\begin{abstract}
One of the stressors for soldier's wife that potentially affect their mental health is the deployment or assignment of their husband for 3-12 months apart from his wife and children. Wives of soldiers must have resilience, the ability to survive or bounce back from the stresses of life. The aim of this study is to evaluate the risk and protective factor in the resilience development of Indonesian Navy soldier's wives during the deployment of husbands. This study used a qualitative case study approach. The respondents were 7 wives of Indonesian Navy soldiers whose husbands were on duty or had served for 3 months or more, and had been married for at least 1 year. The data interpretation technique used interpretative thematic analysis. The study results showed three sources of protective factors, including individual, family, and environmental character. The biggest risk factor was when the child become sick or the wives themselves is sick. The internal protective resilience factors including independence, sociability, humorous, skills, and work experience. The external protective resilience factor including social support, mainly from the family (parents or in-law).
\end{abstract}

Keywords: resilience, risk factor, protective factor, Indonesian Navy soldier's wives.

\section{INTRODUCTION}

Deployment affects military partners in many way [1]. The deployment causes the wives to have less control over their husbands, have difficulty in communication with their husbands, worry about their husbands' safety, and lack of knowledge about the husband's conditions in the deployment area. When the husbands go on duty, soldiers' wives experience isolation or lack of social support, increased stress on household duties, and emotional or psychological health problems [2]. Deployment is considered to be stressful events or stressors requiring coping management and is considered to be the greatest predictor of mental and physical wellbeing [3]. Marnocha [4] states that before, during, and after deployment, military wives are in a transitional and vulnerable state. In the context of daily stress, Zautra [5] states that resilience is defined as the ability to quickly recover from the negative effects of stressful events and sustain positive adaptation when stressors come on repeatedly. During the husband's deployment, the wives deal with various risk factors, so resilience is needed to maintain their mental health and carry out their duties as individuals, mothers, wives, members of Jalasenastri and members of the community in general. Protective factors protect or soften the negative effects of stressors and help the wives become resilient individuals.
The backgrounds for this research are firstly based on the results of the meta-analysis conducted by Grossman [6] on 432 studies on the topic of resilience, it shows that resilience is positively correlated with mental health $(\rho=-.45, \mathrm{k}=120)$, physical health $(\rho=-.36, k=69)$, and subjective well-being $(\rho=.45, \mathrm{k}=48)$. While other studies show that resilience is directly or indirectly correlated with lower levels of general psychological stress, better relationship function, better sleep quality, better overall health (Sinclair et al, 2019), psychological well-being, positive affect [7], mental health, quality of life, marriage satisfaction [8]. Secondly, not many studies have examined the resilience of Indonesian Navy soldiers' wives and protective factors related to the resilience. This is reinforced by the search results on the Google Scholar page and the Garuda page. A search for the keyword "resilience in women" resulted in 48 citations on the Google Scholar page and 9 citations on the Garuda page. On April 24, 2020, a search using google scholar with the keyword "Resilience of TNI's Wife" resulted in 3 citations. Those use quantitative research methods [9][10][11]. Damayanti's research subjects [9] were 6 wives of TNI soldiers who lived in a dormitory when her husband was on duty in a conflict area. Putri [10] studied 6 wives of Indonesian Air Force soldiers who married long distances. Meanwhile, Permatasari [11] used the research subjects of the wives of Brimob members. 


\subsection{Resilience}

Resilience is defined as personal qualities and skills that enable a healthy or successful person to function or adjust themselves in the context of significant stressors or disturbing life events [12] [13][14]. Resilience is an adaptation in the face of stress and adversity [15]. An individual can be said to be resilient, who states that there is a stressor, or is the result of adaptation in the context of stressors [16]. Resilience is closely related to the presence of stressors or difficulties.

When the husband is on deployment, a wife of an Indonesian Navy soldier deals with lot of stressor or adversity at the same time, including being away from relatives/family, worrying about her husband's safety, erratic husband's working hours, spending time alone, balancing family and work matters, adjusting herself with changes related to household duties and other problems that arise as a result of being a single parent. The number of stressors affect the child's upbringing and, furthermore, on their mental health or wellbeing. On this basis, the wives of Indonesian Navy soldiers require resilience.

Masten [17] states that resilience is a dynamic concept that occurs from many processes and interactions that go beyond the boundaries of individual organisms, wherein this process includes variables of close relationships and social support. Resilience is said to be dynamic because the same individual can bring up maladaptive functions at one time and become resilient in development, or vice versa.

\subsection{Risk and Protective Factors}

Theoretically, when an individual dealing with a daily stressor, they cannot be separated from risk factors, and those are protective of stressful events in his life [5][18][19][20]. Lee et al [22] suggest that the psychological factors that correlate with resilience are divided into two categories, including risk and protective factors. Risk factors refer to psychological attributes or dispositions that increase the likelihood of maladaptation, for example, the more people have high levels of stress, the less resilient could be. Meanwhile, protective or promotive factors refer to the characteristics that increase adaptability or have a positive correlation with resilience. Masten [17] states that risk factors generally refer to the prediction of unwanted results. Although it is not certain, a higher probability can cause one or more problems. Risk factors include traumatic experiences and a variety of difficulties that have the potential to hinder development or substantially impair the adaptive function. In summary, it can be said that risk factors are variables that appear before the bad outcome. Furthermore, in his study, Masten [17] (2010) also argues that in the process of a person becoming resilient there are variables called protective factors, namely variables that protect or fortify individuals from the negative effects of stressors. Almeida [18] states that there are 2 protective factors, internal protective factors such as selfesteem, self-efficacy, optimism, emotional regulation, and problem-solving abilities.

Based on Grotberg [21], the three sources of resilience, "I AM", "I HAVE", and "I CAN" were used as the initial concept. Each of those give contribution to variety of actions that can increase the resilience potential. The I AM factors are the individual's internal, personal strengths. These are feelings, attitudes, and beliefs within the individual. The I CAN factors are the individual's social and interpersonal skills. The I HAVE factors are the external supports and resources that promote resilience.

The external protective factors include family support and community involvement. According to Masten [17], protective factors include individual abilities, social support, and protection embedded in religion, community, or other cultural systems. In brief, Masten [17] mentions 6 important protective factors in the system and determines the role changes in life, including intimate or close relationships and social support; intelligence or problem-solving skills; self-regulating skills including the ability to direct or control emotions, and actions; agency, mastery motivation, and selfefficacy; meaning (build meaning and sense of coherence in life); and cultural traditions, particularly religion.

A meta-analysis study conducted by Lee et al [22] indicates that enhancing the protective factors (e.g., self-efficacy, positive affect, and self-esteem) is more effective than reducing the risk factors (e.g., depression and anxiety) to improve resilience. According to Smith et al. [23], most assessment instruments designed to measure resilience are based on facets of resilience that might be facilitated by protective factors. Individuals who 
possess a greater number of attributes associated with resilience are more likely to adapt to a disruptive event successfully, while individuals who have fewer of these attributes will not adapt as successfully.

\section{METHOD}

This research used qualitative case studies. Case studies were chosen as instruments to understand the issues better and to develop or refine theories [24].

The main respondents of the study were the wives of Indonesian Navy soldiers who were assigned for 3 - 12 months or had been left behind for 3-12 months assignment and had been married for at least 1 year. When triangulating the data, interviews were conducted with the officials of the unit where the husbands of the respondents worked. The research was carried out at the Indonesian Navy unit based in Surabaya.

This study used semi-structured interviews as the data collection technique and equipped with field observation data. Data analysis used thematic analysis by finding themes in verbatim that fit the research objectives.

\section{RESULT}

Based on the interview results with the official's unit where the respondents' husbands worked, the following data obtained:

a. Type of task force

- Domestic task force

1. BAIS task force

2. Yomek task force

3. Lombok task force

4. Pam Bangsitnas Papua task force

5. Ambalat task force

- Abroad task force

1. Monusca task force

2. KIZI Konga task force

3. MTF task force

b. The level "on alert" condition in response to developments of the national safety

- Alert level I

All members who are on leave must be summoned to return, permits and leave are canceled, consigned in the battalion for the required time while observing the development of the state national safety, spent the night in the available barracks in the battalion, the food and equipment needed were fully covered by the institution.

- Alert level II

Members sleeping in (Tidur Dalam) or members who had not married carried out consignment, meaning that the member should standby in the unit and might not leave the unit. Members of the Outer Sleep (Tidur Luar) or members who had married could return to their homes but were not allowed to leave the garrison, for example, if they live in Surabaya so they cannot go out of town. Members' leave was canceled or withdrawn by the Unit, so there was no leave and remained on standby.

\section{- Alert level III}

The Sleep In (Tidur Dalam) member was on alert II and the Outer Sleep (Tidur Luar) member was standby at home. Leave permission was permitted, but they should be willing to be summoned immediately to be dispatched for deployment if the security situation escalates to Alert II or Alert I.

c. Social activities to monitor the physical and psychological condition of a Soldier's Wife:

- Dasa Wisma for the soldiers' wives who live in official residence

- District (rayon) system for soldiers' wives who live out of Surabaya

- Jalasenastri event

d. Data of research respondents

Respondents in this study involved 7 wives of Indonesian Navy soldiers whose husbands were or had been on deployment for $3-12$ months and had been married for at least 1 year. Detailed data of respondents were listed in Table 1.

e. Interview Results

From the data analysis results, an overview of the protective factors and risk factors of the wives was obtained as shown in Table 2. 
Table 1. Respondents' characteristics

\begin{tabular}{|c|l|c|c|l|}
\hline No & \multicolumn{1}{|c|}{ Husbands' task force } & $\begin{array}{c}\text { Age } \\
\text { (years old })\end{array}$ & $\begin{array}{c}\text { Number of } \\
\text { children }\end{array}$ & Work \\
\hline 1 & BAIS Irian Jaya (14 months) & 45 & 2 & Did not work \\
\hline 2 & MTF Lebanon (12 months) & 35 & 2 & Did not work \\
\hline 3 & MTF Lebanon (12 months) & 41 & 2 & Work \\
\hline 4 & MTF Lebanon (12 months) & 30 & 2 & Work \\
\hline 5 & BAIS Kalimantan (14 months) & 34 & 2 & Work \\
\hline 6 & MTF Lebanon (12 months) & 33 & 2 & Work \\
\hline 7. & $\begin{array}{l}\text { BAIS Frontier Pulau Sebatek } \\
(14 \text { months })\end{array}$ & 35 & 2 & Did not work \\
\hline
\end{tabular}

Table 2. Risk and Protective Factors

\begin{tabular}{|c|c|c|c|c|c|}
\hline \multicolumn{3}{|c|}{ Risk Factors } & \multicolumn{3}{|c|}{ Protective Factors } \\
\hline Individual & Family & Individual & Family & Individual & Family \\
\hline $\begin{array}{l}\text { - Sick } \\
\text { - Worries of } \\
\text { the husband } \\
\text { safety } \\
\text { - Loneliness } \\
\text { - Worries of } \\
\text { children } \\
\text { future } \\
\text { - Worries } \\
\text { of } \\
\text { husband } \\
\text { cheating }\end{array}$ & $\begin{array}{l}\text { - Sick } \\
\text { children } \\
\text { - Stub-born } \\
\text { children } \\
\text { - Husbands } \\
\text { are not } \\
\text { open about } \\
\text { his feeling } \\
\text { - gawky } \\
\text { husband }\end{array}$ & $\begin{array}{ll}- & \text { the } \\
\text { house is } \\
\text { flooding } \\
\text { the } \\
\text { house is } \\
\text { leaking } \\
\text { - } \quad \begin{array}{l}\text { the } \\
\text { house is } \\
\text { not safe }\end{array}\end{array}$ & $\begin{array}{ll}- & \text { Knitting skill } \\
\text { - } & \text { Skilled at } \\
\text { making onion } \\
\text { peanutes } \\
\text { - } & \text { Experience } \\
\text { being menwa } \\
\text { - } & \text { Understanding } \\
\text { the risk being } & \text { soldiers' wife } \\
- & \text { praying } \\
- & \text { socializing } \\
- & \text { humorous }\end{array}$ & $\begin{array}{ll}- & \text { Parents } \\
- & \text { Parent-in- } \\
& \text { law } \\
- & \text { The } \\
& \text { presence of } \\
\text { children } \\
-\quad & \text { good } \\
\text { comunicati- } \\
-\quad \begin{array}{l}\text { on with } \\
\text { husband }\end{array}\end{array}$ & $\begin{array}{ll}- & \text { Neighbour } \\
- & \text { Support } \\
& \text { from } \\
& \text { related } \\
& \text { institution } \\
- & \text { The } \\
& \text { presence of } \\
\text { household } & \text { assistant } \\
- & \text { Day care } \\
\text { for children } \\
\text { - co-worker }\end{array}$ \\
\hline
\end{tabular}

\section{CONCLUSION}

The are three sources of protective factors, including individual, family, and environmental character. The biggest risk factor was when the child become sick or the wives themselves is sick. The internal protective resilience factors including independence, sociability, humorous, skills, and work experience. The external protective resilience factor including social support, mainly from the family (parents or in-law).

\section{AUTHORS' CONTRIBUTIONS}

This study provides a perspective of resilience from a Navy soldier's wife and effort to develop resilience to the empowerment of the wives in the face of adversity in their life as the wife of Navy soldier.

\section{ACKNOWLEDGMENTS}

Authors would like to thanks the promotor team from Department of Psychology, University of Surabaya, Indonesia, Psychological Service of the
Indonesian Navy, and the Navy Headquarters for funding the research.

\section{REFERENCES}

[1] W.H. Wan, S.N. Haverly, and L.B. Hammer. (2018), "Work, Stress, and Health of Military Couples Across Transitions", P.D. Harms and P.L. Perrewé (Eds.) Occupational Stress and Well-Being in Military Contexts (Research in Occupational Stress and Well Being, Vol. 16), Emerald Publishing Limited, (2018). 69-90. DOI: $10.1108 /$ S1479-355520180000016005

[2] K.P. Lufkin. An exploratory study of marital and quality of life ratings among male spouses of military members. Contemporary Family Therapy, 39(3) (2017) 162-171

[3] D.L. Padden, R.A. Connors, J.G. Agazio. Stress, coping, and well-being in military spouses during deployment separation. West. J. Nurs. Res. 33(2) (2011) 247-267. DOI: $10.1177 / 0193945910371319$ 
[4] S. Marnocha. Military wives' transition and coping: Deployment and the return home. $\begin{array}{llll}\text { ISRN Nursing } 2012 \quad \text { (2012) } & 1-8\end{array}$ DOI:10.5402/2012/798342

[5] A.J. Zautra. Emotions, stress, and health. New York: Oxford University Press. 2003

[6] M.R. Grossman. Clarifying the nature of resilience: A meta-analytic approach. Psychology. 2014.

[7] E. Sagone, M. L. Indiana, 2013, The Relationship of Positive Affect with Resilience and Self-Efficacy in Life Skills in Italian Adolescents, Procedia Soc Behav. Sci. 92 (2013) $838-845$.

[8] M.B. James, H. Mahzad. A Model of resilience and marital satisfaction. J. Soc. Psy. 157(5) (2017) $588-601$, DOI:10.1080/00224545.2016.1254592

[9] F. Damayanti. Resiliensi Istri Tentara (TNIAD) yang Tinggal di Asrama Ketika Suami Bertugas di Daerah Konflik. Prof. Med. J. 2019

[10] A.L.K. Putri. Resiliensi pada Istri Prajurit TNIAU dalam menjalani pernikahan jarak jauh. Thesis. 2018. Available from http://eprints.ums.ac.id/63039/8/NASKAH\%2 OPUBLIKASI.pdf

[11] A.P. Permatasari, Siswati, 2017. Hubungan antara self-compassion dengan resiliensi pada istri anggota satuan Brigade Mobil Kepolisian Derah Jawa Tengah (Satbrimob Polda Jateng). J. Empati. 6(4) (2017) 362-367. Available from https://ejournal3.undip.ac.id/index.php/empati /article/view/20109.

[12] K.M. Connor, J.R.T. Davidson. Development of a new resilience scale: The ConnorDavidson Resilience Scale (CD-RISC). Depress Anxiety 18 (2003) 76-82. DOI: 10.1002/da.10113.

[13] S.S. Luthar, D. Cicchetti, B.E. Becker, B. E. The construct of resilience: A critical evaluation and guidelines for future work. Child Development, 71 (2000) 543-562.

[14] A.S. Masten, J. Obradovic, K.B. Burt. Resilience in emerging adulthood:
Developmental perspectives on continuity and transformation. In J. J. Arnett \& J. L. Tanner (Eds.), Emerging adults in America: Coming of age in the 21st century. Washington, DC: American Psychological Association Press. 2006. pp. 173-190.

[15] American Psychological Association Dictionary of Psychology. 2016.

[16] M. Rutter. Proceeding from observed correlation to causal inference: The use of natural experiments. Pers. Psy. Science. 2 (2007) 377-39.

[17] A.S. Masten, M.O. Wright, M. O. Resilience over the lifespan: Developmental perspectives on resistance, recovery, and transformation. In J. W. Reich, A. J. Zautra, \& J. S. Hall (Eds.), Handbook of adult resilience. The Guilford Press. 2010. pp. 213-237.

[18] D.M. Almeida. Resilience and vulnerability to daily stressors assessed via diary methods, current directions in psychological science, Volume 14-Number 2, The Pennsylvania State University. 2015.

[19] R.S. Lazarus. Stress and emotion: A new synthesis. New York: Springer. 1999.

[20] S. Lazarus, S. Folkman. Stress, appraisal, and coping. New York: Springer. 1984.

[21] E.H. Grotberg. Tapping your inner insight: How to find the resilience to deal with anything. New Harbinger Publication. Inc., Oakland, Canada. 1999.

[22] J.H. Lee, S.K. Nam, A-R. Kim, B. Kim, M.Y. Lee, S.M. Lee. Resilience: A Meta-Analytic Approach. J. Couns. Dev. 91(3) (2013) 267279

[23] B.W. Smith, J. Dalen, K. Wiggins, E. Tooley, P. Christopher, and J. Bernard. The brief resilience scale: Assessing the ability to bounce back. Int. J. Behav. Med. 15 (2008) 194-200.

[24] E.K. Poerwandari. Pendekatan kualitatif dalam penelitian psikologi. Jakarta: Universitas Indonesia. 2005. 